${ }^{\bullet}$ Entomologica Fennica. 3 July 2002

\title{
The Hilara species described by L. Oldenberg, with description of a new species from Lapland (Diptera: Empididae)
}

\author{
Milan Chvála
}

\begin{abstract}
Chvála, M. 2002: The Hilara species described by L. Oldenberg, with description of a new species from Lapland (Diptera: Empididae). - Entomol. Fennica 13: 65-78.

Three species of Hilara Meigen, described by L.Oldenberg in 1916 ( $H$. caerulescens, $H$. coracina, $H$. perversa), are redescribed and the lectotypes are designated. Hilara borealis Oldenberg (new name proposed by Oldenberg for the alpine Hilara czernyi Strobl, 1910, not Strobl, 1909) is shown to be a taxon comprising two geographically different populations, that from northern Fennoscandia is described as new to science, Hilara lapponica sp.n. The main differential features of all species are illustrated. Epigamic behaviour and swarming activity is described for $H$. borealis.
\end{abstract}

Milan Chvála, Charles University Prague, CZ-128 44 Praha 2, Czech Republic;E-mail:mchvala@natur.cuni.cz

Received 27 December 2001, accepted 26 February 2002

\section{Introduction}

The German entomologist Lorenz Oldenberg published many papers on Diptera between 1910 and 1927, mainly on higher Brachycera, particularly Empidoidea and Acalyptrates. He was a special authority on high mountain insects, and his collecting activity was concentrated on the Alps and the Carpathians. His Empididae studies were mainly focused on the high mountain Rhamphomyia species but his single paper on the Hilara species (Oldenberg 1916) is of importance. His descriptions and differential diagnoses of the new Hilara species clearly showed that Oldenberg understood the genus well, which cannot be said about some of his contemporaries who were also describing new species. Oldenberg's good knowledge of the genus Hilara may be demonstrated well by the fact that he closely collaborated at that time with James E. Collin, and it was he who correctly recognized for example Hilara medeteriformis Collin in Europe. When describing this species, Collin (1961) adopted the specific name (epithet) first proposed by Oldenberg.

Oldenberg was well aware how difficult the genus Hilara was and how uncertain and risky it would be to describe new species without a good knowledge of types for taxa already described. This is well demonstrated by the empidid collection in the Deutsches Entomologisches Institut (DEI) at Eberswalde where Oldenberg's collection includes thirty-three new Hilara species with unpublished Oldenberg MS names, most of them being described later by subsequent authors as valid species. There are some also in Collin's "Palaearctic Collection" in Oxford; for instance the continental specimens of Hilara morata Collin, 1927 bear also an unpublished MS name Hilara angusticauda Oldenberg, and there are many more such examples.

Although Oldenberg presented very detailed descriptions of the new Hilara species and, as pointed out already above, his differential diagnoses were clear and unusually complete, the spe- 


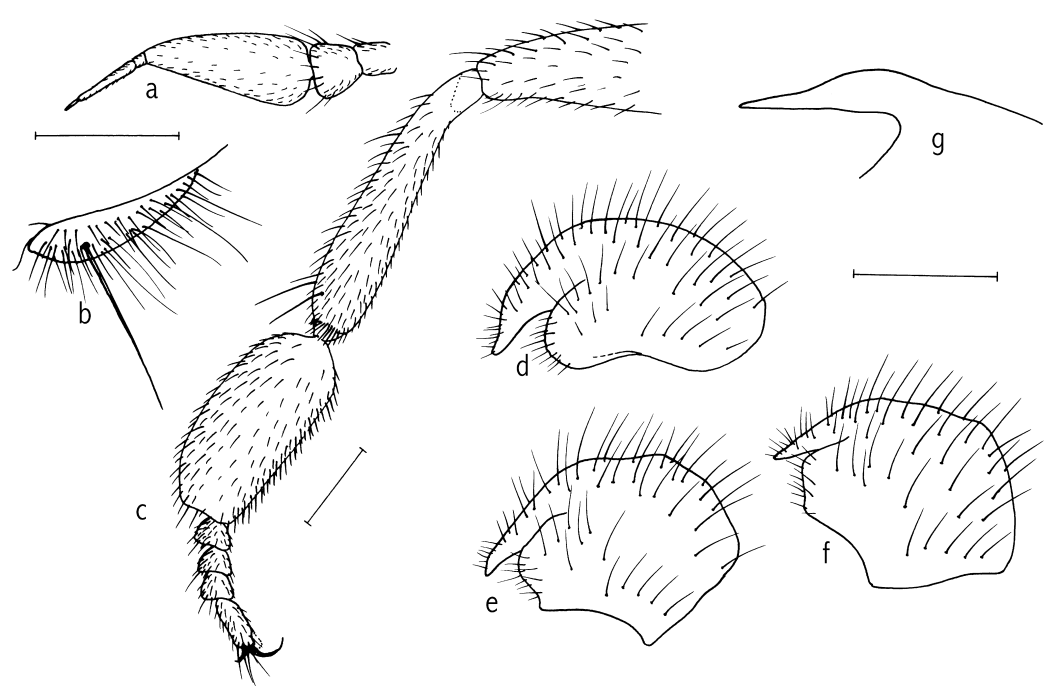

Fig. 1. Hilara borealis Oldenberg, male (Austria, Kaiserau). - a. Antenna, inner view. — b. Palpus, lateral view. - c. Fore leg with tip of femur, anterior (inner) view. d-f. Lateral genital lamella in 3 different views. $-d$. Dorsolateral view. - e. Lateral view. - $f$. Ventrolateral view. - g. Tip of hypandrium, lateral view. Scale $0.2 \mathrm{~mm}$.

cies described by him remained unrecognised or were overlooked by most of the subsequent dipterists. This might be because all species of Hilara described or named by Oldenberg (1916) were of continental and mainly alpine distribution, and thus not included by Collin (1961) in his excellent monograph on British flies. Consequently, the Hilara species described by Oldenberg were omitted by European dipterists in the last forty years, although some of them, for instance Hilara coracina or H. borealis, are widely distributed in continental temperate Europe.

Oldenberg (1916) described in his only Hilara paper three new alpine species (Hilara perversa, $H$. caerulescens, $H$. coracina) and added one replacement name (Hilara borealis, a new name for Hilara czernyi Strobl, 1910 [Austria], not 1909 [Spain]). On the other hand, Hilara nana Oldenberg, 1924 was only a published von Roser's manuscript name, a still unrecognised species and, furthermore, an unavailable name being preoccupied by Hilara nana Macquart, 1827 (a synonym of Hilara chorica [Fallén, 1816]).

\section{Material and methods}

The present paper is primarily based on a thorough study of the Hilara species of many institutional collections including revision of types. The most important were the Olden- berg Collection - deposited in Eberswalde (Germany), the Strobl Collection in Admont (Austria), and the Fennoscandian collections in Copenhagen (Denmark), Lund (Sweden), and Helsinki (Finland).

Abbreviations of collections where the documentary specimens are located are, as follows: BSA - Collection G. Strobl, Benediktinerstift Admont (Austria); CBM Collection B. Merz, Muséum d'Histoire Naturelle, Genève (Switzerland); CBP — Collection M. Barták, Prague (Czech Republic); CUP — Collection M. Chvála, Charles University, Prague (Czech Republic); DEI - Deutsches Entomologisches Institut, Eberswalde (Germany); ETHZ Eidgenössische Technische Hochschule, Zürich (Switzerland); MTD - Staatliches Museum für Tierkunde, Dresden (Germany); SMO — Silesian Museum, Opava (Czech Republic); UZMC — Universitetet Zoologisk Museum, Copenhagen (Denmark); UMO — University Museum, Oxford (U.K.); UZMH - University Zoological Museum, Helsinki (Finland); ZIL - Zoologiska Institutionen, Lund (Sweden); ZMB - Zoologisches Museum der HumboldtUniversität, Berlin (Germany).

The following abbreviations are used for thoracic bristles: $a c r-$ acrostichal, $d c$ - dorsocentral, $h$ - humeral, $i h$ - intrahumeral, $n t p l$ notopleural, $p h$ - posthumeral, $s c$ — scutellar. In addition the following is also used: MT (in "Material examined") — Malaise trap.

\section{List of species}

\section{Hilara borealis Oldenberg, 1916 (Fig. 1)}

Hilara czernyi Strobl, 1910: 69 (Austria), not Strobl, 1909: 176 (Spain). 
Hilara borealis Oldenberg, 1916: 172, new name for Hilara czernyi STROBL, 1910, not Strobl, 1909 (partim).

Lectotype designation. This species was described by Strobl (1910) as Hilara czernyi from specimens taken "An Bergbächen bei Admont (Styria)". There is, in the Strobl, "Nachträge zu Empidiae" Collection in Admont a male and two females (see also Chvála [1971]) standing beside a pink original label "Hil. Czernyi m.i.l. Admont ... 26/8 10 " 2 오 Strobl"; the male (body length $3.2 \mathrm{~mm}$, wing $3.2 \mathrm{~mm}$ ) was loaned for study by the author in 1970 and is hereby designated as lectotype of Hilara czernyi Strobl, 1910 (not 1909); the two females are paralectotypes.

Because of the homonymy Oldenberg (1916) proposed for Hilara czernyi Strobl, 1910 a new name Hilara borealis, stating that he had found this species "nicht nur in den Alpen (St.Moritz, Gastein) und im Glatzer Gebirge (Wölfelgrund), sondern auch in Lappland (Gellivare)". The specimens (including some others collected by Oldenberg later in 1921 and 1928) are well preserved in the Oldenberg Collection in Eberswalde and are fully listed below in the paragraph "Material examined". The Scandinavian specimens from Gellivare (= Gällivare, Lule Lappmark) belong, however, to a different species described below as Hilara lapponica sp.n.

Diagnosis. Medium sized (body about 3-3.5 mm long) dull brownish-black species with black legs and halteres, legs short and stout with very shortened tarsomeres; wings clear. Occiput and a broad frons dull black, scutum with three coalescent black stripes on brownish-grey background, $a \mathrm{cr}$ very small, biserial.

Redescription. Male. Frons and face very conspicuously broad, face and small patch above antennae grey dusted, otherwise frons and occiput dull velvety black. Pair of ocellar bristles fine, long; frontal bristles clearly shorter, as long as upper postocular setae; upper occipital hairs and bristles black, those below neck whitish. Antenna (Fig. 1a) deep black, style half as long as 3rd segment. Palpus (Fig. 1b) black, with grey tomentum, ventrally with rather dense short black bristles; single long bristle in apical third. Labrum much shorter than the height of the head.

Thorax black, with dark grey dusting; scutum almost uniformly brownish viewed from in front with indication of darker median stripe, in dorsal view with three black stripes on lines of bristles (lateral ones very broad), humeri, prescutellar depression and scutellum very grey; viewed from behind mesonotum almost uniformly black. All mesonotal bristles black and fine: acr numerous and narrowly regularly 2 -serial, similar $d c$ uniserial, all much shorter than antennal style; large bristles in full number including $3 \mathrm{ntpl}$, last 2 prescutellar pairs of $d c$, and 2 pairs of $s c$, all fairly long but very fine. Long fine black pronotal bristle on each side, prothoracic episternum and sides of prosternum with minute fine brownish (scarcely pale) hairs. Spiracles deep black on grey background.

Wing clear, somewhat irridescent, with blackish veins and a long brownish stigma; costal bristles fine. Squamae blackish with pale fringes, halter uniformly black.

Legs rather short and stout, everywhere densely short black pubescent and practically without distinct bristles except for the usual long anterior bristles on mid femur; hind femur with longer dorsal hairing and some longer bristly hairs anteroventrally before tip, though only apical one nearly as long as femur is deep. All tibiae rather short, fore tibia (Fig. 1c) spindle-shaped, on inner side somewhat reddish pubescent; fore basitarsus broadly ovate, covered with only short pubescence, no bristles; tarsi very short on all pairs, tarsomeres 2-4 on anterior four legs (Fig. 1c) very short, clearly wider than long; last tarsomere on all legs with distinct long apical hairs.

Abdomen black, brownish-grey pollinose, rather subshining in dorsal view, more dull brownish in lateral view; all hairs on at least basal segments pale to brownish, hind-marginal bristles fine and small, black. Genitalia (Fig. 1d-f) small, black, lateral lamella covered with long black hairs, apical projection broad at base, apically pointed, varying in shape in different points of view (Fig. 1d-f); tip of hypandrium simple and slender.

Length. body 3.0-3.8 mm, wing 3.0-3.7 mm.

Female. Resembling male in all main characters; anterior four tibiae perhaps less stout than in male, and tarsomeres 2-4 on anterior two pairs as long as deep; hind tibia distinctly flattened and curved, nearly as thick as corresponding femur, covered with short hairs. Abdomen duller grey, almost bare, only basal 2 segments at sides with fairly long, dense pale hairing. Length: body $3.0-3.6 \mathrm{~mm}$, wing $3.3-3.7 \mathrm{~mm}$. 
Differential diagnosis. Hilara borealis is a member of a complex of species characterised by the very broad frons and face (frons, at least partly, and occiput dull velvety black, face light grey), black halteres, rather short and stout blackish legs devoid of distinct bristles, and usually very clear irridescent wings with contrasting thick dark veins. In addition to the following Hilara lapponica sp.n., $H$. medeteriformis Collin, $H$. calinota Collin, $H$. lacteipennis Strobl and H. pruinosa Wiedemann should also be classified in this complex (the latter species is somewhat intermediate and has several characters of the H. maura-group). Hilara borealis may easily be differentiated by the small narrowly biserial $\mathrm{acr}$, the shortened antennal style one-half length of 3rd segment, and by the very short tarsi in particular. The female of $H$. borealis has many characters which are very similar to the spring species $H$. brevivittata Macquart, differing chiefly by pale abdominal pubescence (at least at base of abdomen) and by the presence of a broad blackish median stripe on acr bristles clearly visible in anterodorsal view. On the other hand, the structure of antennae, frons, face and tarsi (including a set of long hairs at tip of last tarsomere), and especially the curved flattened hind tibiae, are almost identical in both these species.

Distribution. Central European species, described from Austria, where it is fairly common, and since then also found in Poland, Czech Republic, Slovakia, Germany and Switzerland. Up to now only a poorly known species, not recorded, for instance, by Straka (1975) in the former Czechoslovakia, nor by Niesiolowski \& Krysiak (1996) from Poland, though recorded already by Oldenberg (1916) from Polish Silesia (see below). All recent records of the national checklists (Czech Republic and Slovakia, Germany, Switzerland) are based on the author's recent identifications. Straka misidentified this species from the former Czechoslovakia either as Hilara woodi Collin (= H. pseudochorica Strobl) or H. longivittata Zetterstedt (see Material examined).

Epigamic behaviour. Swarming activity has been observed in June 1997 by the author in the Austrian Alps of Styria, at about 1100 m (near the castle Kaiserau in Gesäuse). Male swarms were observed both above streams and above standing water (above a water reservoir for artificial snow in ski area). In both cases the swarms (about $1 \mathrm{~m}$ long and $0.5 \mathrm{~m}$ wide) consisted of preyless males flying in horizontal flight at most up to $0.5 \mathrm{~m}$ high above water. The swarms above about $2 \mathrm{~m}$ wide stream Liechtmessbach consisted of about 5-10 males flying in shade close to the banks where the water was almost still. The males copulate without prey transfer with entering females. Swarms in sunlight above standing water were more numerous, a swarm consisted generally of 20-30 preyless males. Males of Hilara borealis were observed also slowly circling above small shallow patches of water along banks of rivers (Styria, Hall near Admont 16.V.2000), or even skimming the water surface of rivers and streams (Czech Republic, southern Bohemia in June 2001).

Material examined (from north to south). Poland: Glatzer Gebirge, Wolfelsgrund (= Sniednicki Park Krajoobrazowy, Miedzygórze) 23.-17.VI.1905 $60^{7} 1$ \&, Reinerz (= Gory Bystrzyckie, DusznikiZdroj) 5.-10.VII.1916 1 O’ 8 O leg. L. Oldenberg (DEI). Czech Republic: Krkonoše Mts, Pec p. Sněžkou, Velká Pláň 850 m, 28.V.2001 1 ơ leg. M. Chvála; Bohemia or., Běleč n. Orlicí 26.V.1995 1 o' leg. B. Mocek; Bohemia centr., Davle, Zahořanský potok stream 2.VI.1994 1 @ leg. M. Chvála; Bohemia mer., Sepekov, River Smutná 31.V.2001 1 ơ, 14.-16.VI.2001 3 ơ (skimming), Božetice-Radihošt, River Smutná, 5.VI.1999 1 ơ, Jistebnice, Jezviny (stream) 30.V.1993 1 o",

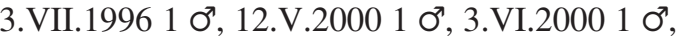
8.VI.2001 2 O’, 24.VI.2001 1 ठ’ (skimming), all leg. M. Chvála (CUP); Vráž u Písku (drowned in a puddle) 400 m, 5.VI.2001 2 o leg. Barták \& Kubík (CUP); Šumava Mts: Malá Niva (peat bog) 750 m, 5.VII.1988 3 ơ 8 우 (H.woodi Coll. det. Straka 1991), 29.IV.-16.VI.1999 MT 1 \&, 16.VI.20.VII.1999 MT 2 ㅇ leg. M. Barták (CUP); Prášily, River Křemelná 810 m, 8.VII.1994 1 ơ, 1.VII.1995 2 ơ leg. M. Barták; Modrava 8.VII.1992 4 Ơ leg. J.Roháček; Popelná 880 m, 3.VII.1988 1 ơ leg. M. Barták (H.woodi Coll. det. Straka 1991); Mrtvý luh near Volary 11.VII.1969 1 ㅇ leg. J. Ježek (all CUP); Chalupecká slaţ 860 m, 2.VI.-5.VII.1996 MT 2 ơ 4 q, 4.VII.-5.VIII.1996 2 ㅇ, Jezerní slat 5.-7.VII.1996 1 ㅇ, Kyselovský les (peat bog) 725 m, 17.V.1997 1 o, Rokytnická slat 16.VI.-21.VII.1999 2 \&, all leg. M. Barták (CBP); Borová Lada-Volary (car net) 28.VI.1992 2 ơ, Horská Kvilda-Borová Lada (car net) 


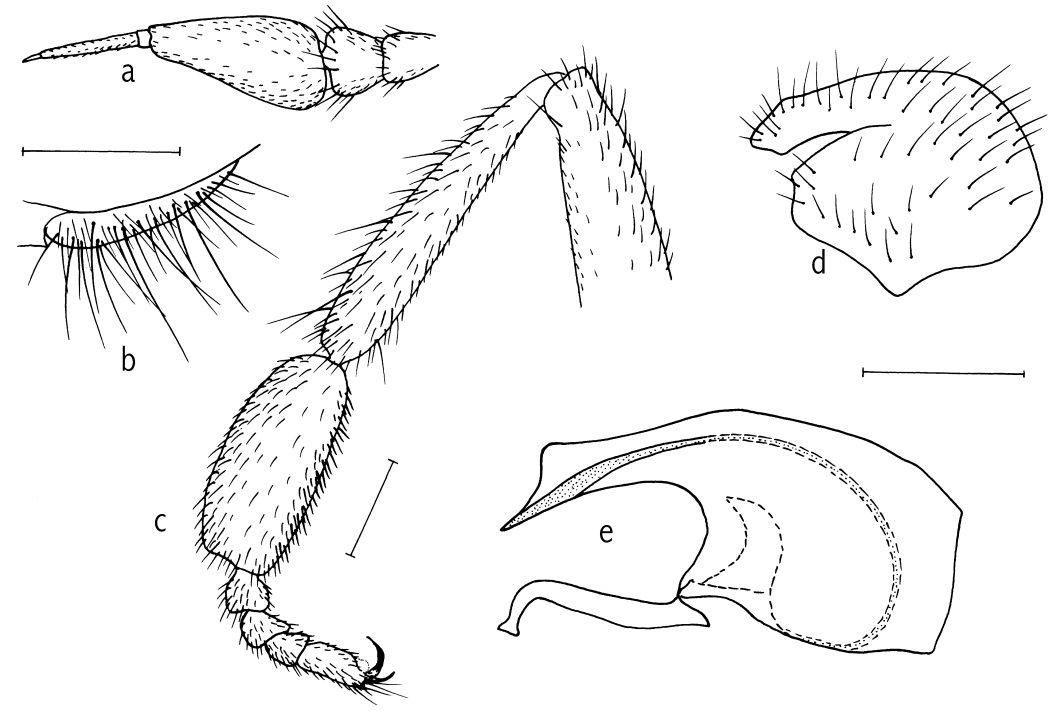

Fig. 2. Hilara lapponica sp.n., paratype male (Sweden, Nb., Smedsbyn). - a. Antenna, inner view. - b. Palpus, lateral view. - c. Fore leg with tip of femur, posterior view. - d. Lateral genital lamella, lateral view. - e. Hypandrium with postgonite in lateral view. Scale $0.2 \mathrm{~mm}$.

28.VI.1992 4 O’ 2 o all leg. M. Barták (all H.longivittata Zett. det. Straka 1993) (CUP). Moravaia bor., Horní Bečva 26.VI.1975 1 O leg. M. Barták (H.woodi Coll. det. Straka 1981). Slovakia: Malá Fatra Mts, Bystrička 650m, 1.VI.1983 3 o leg. M. Chvála (CUP). Slovakia centr., Pol'ana B. R., Čierny Potok 7.VI.1999 $10^{7}$ (at light), Sihla, Kamenský potok valley 11.VI.1999 1 O’ leg. J. Roháček (SMO); Slovakia or., Snina, River Cirocha 2.VI.1984 1 O’ leg. J. Roháček (H.longivittata Zett. det. Straka 1988) (CUP); Poloniny Mts, Nová Sedlica, Beskid 9.VI.1966 $40^{7}$ leg. M. Chvála (CUP). Austria: Salzburgland: Gastein 29.VI.1907 1 ơ, 1.VII.1907 1 O leg. L. Oldenberg (DEI); Obertauern, Tweng, Taurbach stream 1200 m, 17.VI.2000 2 o"; Steiermark: Schladming, Untertal 1000 m, 6.VII.2001 1 O' 1 o ; Schladminger Tauern, Sölkerpass $1300 \mathrm{~m}$, 7.VII.2001 1 ơ 1 O; Ennstaleralpen, Oberlaussa, Polzanbach stream $850 \mathrm{~m}, 18$. VI.2000 4 o', Hall near Admont 5.VI.1996 1 o', 16.V.2000 2 o", Ziernitz 9.VI.1996 2 o’ 1 o, Kaiserau 1100 m, 6.VI.1996 9 ơ 7 \% , 10.-15.VI.1997 (swarms) 46 o' 8 \&, all leg. M. Chvála (CUP); Gesäuse, Johnsbach 8.vi.1996 3 0’, St. Gallen, Buchaubach 9.VI.1996 $20^{7}$ leg. M. Chvála (CUP). Kärnten: Hermagor 25.-30.V.1928 4 0', Mauthen 5.VII.1928 1 ㅇ, Kl. Fleiss 14.VIII.1907 2 O’, all leg. L. Oldenberg
(DEI). Switzerland: Engiad. Bassa, Ramosch 1050 m, 11.VII.1961 1 o leg. L. \& F. Keiser (CUP); VS, Visperterminen 1900-2300 m, Rothorn-Giw, 30.VII.1998 1 ơ leg. Merz \& Bächli (ETHZ). Zürich-Katzensee 440 m, 19.IV.1997 1 o leg. B. Merz (CBM). Madesino VII-X 1 ơ ex Coll. Escher-Kündig (ETHZ).

\section{Hilara lapponica sp.n. (Fig. 2)}

Hilara borealis Oldenberg, 1916: 172, new name for Hilara czernyi , SтRовL, 1910, not Strobl, 1909 (partim)

Holotype. O': Finland: KB, Yläluostari, 1.vii.1937 leg. Nordman (UZMH).

Paratypes. Finland: Li, Utsjoki $1 \mathrm{O}^{7}$ leg. R. Frey; Utsjoki, Tenojoki 1 \& leg. W. Hackman, R. Frey; Li, Saariselkä 1 익. leg. B. Poppius. KB, Yläluostari 2 ơ $^{\prime}$ q leg. R. Frey (all UZHM). "Lapponia" 1 O leg. Palmén (UZMH). Russia: LPS, Petsamo 2 o’ 2 ㅇ leg. R. Frey; LPS, Latto 1 ㅇ leg. Platonoff (UZMH). Sweden: Lu-Lpm., Gällivare 8.VII.1910 4 O’ 9 ㅇ leg. L. Oldenberg (DEI). Nb., S. Sunderbyn 14.VII.1975 1 ơ leg. H. Andersson (CUP). Nb., Ned. Lul. Smedsbyn (Kärr och äng vid sjö) 2.VII.1963 1 Oo $^{\top} 2$ O leg. H. Andersson (ZIL). Sm., Växjö, Helgaryd 20.VI.1988 1 ㅇ, 25.VI.1988 1 일. R. Danielsson (ZIL). 
One pair from Gällivare (on one pin) from the Oldenberg Collection in DEI bears an original Oldenberg label "H.Czernyi Strobl det. Old.", and another pair bears a label "borealis $\mathrm{m} .=$ Czernyi Strobl II, Fehler".

Diagnosis. North Fennoscandian mediumsized (body about $3.5 \mathrm{~mm}$ long) dull greyish-black species with a broad frons and face, closely related to the Central European H. borealis. Differing chiefly by the 4-serial $a c r$, longer antennal style, rather reddish-brown abdominal pubescence, by the different bristling on head, palpi and legs, and differently shaped male genitalia.

Description. Male. Frons and face very broad, former velvety black except for small grey patch above antennae, face dull dark grey; occiput velvety black, though almost grey in some views. Pair of ocellar and frontal bristles equally long and strong, clearly longer than upper occipital hairs. Upper occipital bristles black, those below neck rather reddish-brown or light brown, not pale as in H. borealis. Antenna (Fig. 2a) reddish or dark brownish on basal segments, 3rd segment black, style longer than in $H$. borealis, about 3/4 length of 3rd segment. Palpus (Fig. 2b) greyishblack, densely black bristled beneath, with 4-5 equally long stronger bristles. Labrum much shorter than the height of the head.

Thorax dull dark grey on pleura, mesonotum brownish-grey with variable dark pattern: scutum clearly brownish viewed from in front, in anterodorsal view with blackish stripes on lines of bristles, and altering narrow darker grey stripes be- tween rows; in posterior view scutum black, leaving prescutellar depression and scutellum greyish. All hairs and bristles on thorax blackish: $a c r$ irregularly 4-serial, at least anteriorly, $d c$ uniserial, all small and fine, but last 3 prescutellar pairs of $d c$ bristle-like; all other bristles in full number, rather long but fine including $h, p h$ and $i h$, last $n t p l$ of the 3 present, $p a$ and inner pair of $4 s c$ longest. Pronotum with a long black bristle on each side, prothoracic episternum with several fine dark hairs, similar shorter but numerous hairs also at sides of prosternum. Spiracles black.

Wings clear, iridescent, with contrasting dark veins, faint brownish stigma, and small black costal bristle. Squama dark with pale fringes, halter blackish with brown stalk.

Legs rather short and stout, densely short blackish pubescent, more reddish-brown on tibiae. Fore femur without longer bristles, mid femur with the usual anterior bristles, and at least 2 long black bristly-hairs anteroventrally before tip; hind femur with longer bristly-hairs dorsally (though much shorter than femur is deep), anteroventrally before tip with 4 to 5 very long bristles at least as long as femur is deep, some of them coarse and very black. Tibiae generally short and not distinctly bristled except for preapical bristles; fore tibia (Fig. 2c) with usually 2 longer dorsal bristles, hind tibia with similar 2 or 3 bristles dorsally nearly as long as tibia is deep. Tarsi very short, tarsomeres 2 to 4 on all pairs at most as long as deep; fore basitarsus (Fig. 2c) very swollen and regularly long ovate, longer than rest of tarsus;

Table 1. The differential features of Hilara lapponica sp.n. and $H$. borealis.

\begin{tabular}{|c|c|c|}
\hline & H. borealis Oldenberg & H. lapponica sp.n. \\
\hline acr & 2-serial & 4-serial \\
\hline wing alula & with blackish fringes & with pale fringes \\
\hline palpus & $\begin{array}{l}\text { with black hairs and a single very long black } \\
\text { bristle beneath }\end{array}$ & densely long black bristled ventrally \\
\hline hind femur & $\begin{array}{l}\text { av before tip with short bristly hairs and } 1 \text { longer } \\
\text { bristly hair }\end{array}$ & with 3-4 long av bristles before tip \\
\hline mid femur & $a v$ before tip with short hairs & with several long av bristly hairs \\
\hline humeral bristle & small, fine & $h, i h, p h$ bristles distinct \\
\hline frontal bristles & half as long as ocellars and very fine & as long and stout as ocellars \\
\hline antennal style & shorter, half length of 3rd segment & longer, $3 / 4$ length of 3rd segment \\
\hline antenna & uniformly black & basal segments brownish \\
\hline halter & uniformly black & stalk brownish \\
\hline abdomen & pale pubescent at base & light brownish pubescent \\
\hline
\end{tabular}




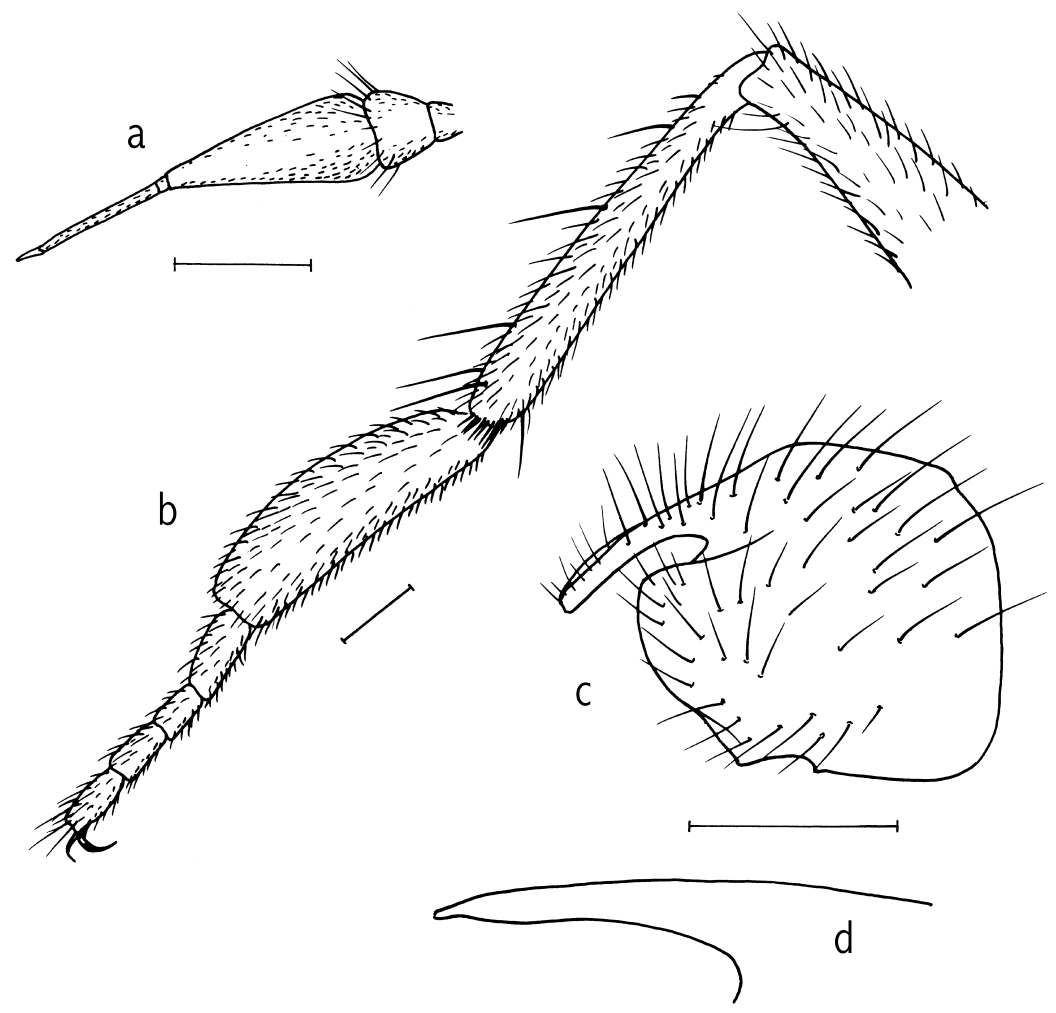

Fig. 3. Hilara caerulescens Oldenberg, male (Switzerland, VS, Leuk-Platten). - a. Antenna, inner view. - b. Fore leg with tip of femur, anterior (inner) view. - c. Lateral genital lamella, lateral view. - d. Tip of hypandrium, lateral view. Scale $0.2 \mathrm{~mm}$.

last tarsomere on all pairs with several long, fine, dorsal hairs at tip as in H.borealis.

Abdomen black, finely greyish dusted and short somewhat reddish to brownish pubescent, at least on anterior segments; general appearance of terga is from subshining black to rather dull grey, depending on point of view and light; hindmarginal bristles distinct, black. Genitalia (Fig. 2d-e) rather small, compared with $H$. borealis lateral lamella clearly shorter dark pubescent, terminal projection broader right up to shortly pointed tip, and apex of hypandrium bears hooklike projection dorsally before tip.

Length. body 3.1-3.7 mm, wing 3.3-3.8 mm (holotype body $3.6 \mathrm{~mm}$, wing $3.7 \mathrm{~mm}$ ).

Female. Resembling male in all details including bristling of legs (fore tibia dorsally, mid and hind femora anteroventrally before tip) but tarsi simple and apparently longer, tarsomeres $2-4$ on hind legs somewhat longer. Abdomen with similar short rather brownish pubescence, hind-mar- ginal bristles on terga long and fine, and rather paler, more brownish than in male. Length: body 3.2-3.5 mm, wing 3.2-3.6 mm.

Differential diagnosis. Hilara lapponica sp.n. is very similar to $H$. borealis, with which it is compared in the above description. The main differential features are given in Table 1.

Distribution. Northern European species known from the Finnish Lappland south to Karelia borealis, from the NW of European Russia (LPS), and from the north of Sweden (Lule Lappmark, Norrbotten), south to Småland. Adults are known from the second half of June to the mid of July.

\section{Hilara caerulescens Oldenberg, 1916 (Fig. 3)}

Hilara caerulescens Oldenberg, 1916: 168 Hilara chvalai Straka, 1976: 6

Lectotype designation. The species was described by Oldenberg (1916) from the Italian Alps, from 
a locality about $15 \mathrm{~km}$ east from Bolzano, based on $16 \sigma^{7}$ and 1 o taken "in Tschamintal (Tiroler Dolomiten) 11 bis 26 Juni 1914, 1300 bis $1400 \mathrm{~m}$ hoch dort kreisten die Tierre dicht über Wasserlachen an überfluteten Stellen des Weges und an Tümpeln des Tschaminbachs". There are altogether 12 syntypic males in the Museum in Berlin, 9 ơ from Tschamintal (12.6.14 5 o', 17.6.14 $10^{7}, 20.6 .1410^{7}, 21.6 .1410^{7}$ labelled "caerulescens Old." and 27.6.14 $1 \mathrm{O}^{7}$ ), and 3 males labelled "Tiers" (= Tires) which also belong to the syntypic series (16.6.14 $\left.1 \mathrm{O}^{7}, 22.6 .142 \mathrm{O}^{7}\right)$. One male in perfect condition (body length $4.7 \mathrm{~mm}$, wing $5.3 \mathrm{~mm}$ ) from Tschamintal (12.6.14) is hereby designated as lectotype of Hilara caerulescens Oldenberg and it was labelled so in 1999.

Synonymy. Hilara chvalai Straka, 1976 was described from $20^{7}$ and 3 \%, taken by the author on 16th May 1964 in the Zadielska dolina valley, southern Slovakia; the holotype $\sigma^{7}$ and 1 paratype ㅇ labelled "Slovakia mer., Zadielska dolina 16.5.1964 leg. M.Chvála" are deposited in the Museum Andrej Kmet in Martin, Slovakia, the rest of the paratype series is in the author's collection. The species is conspecific with Hilara caerulescens Oldenberg and becomes its junior synonym. This synonymy was already mentioned without explanation in the checklists of the Czech and Slovak Republics (Chvála 1997b) and of Switzerland (Chvála et al. 1998).

Diagnosis. Large, body about 4-5 mm long, uniformly dull dark bluish-grey species with all hairs and bristles long, black; body, legs and halteres uniformly black. Frons and occiput grey, latter not dull black from any point of view; $\mathrm{acr}$ 4-serial, $d c$ uniserial posteriorly, both on distinct brownish-black stripes. Antennae long but style short, half as long as segment 3.

Redescription. Male. Head uniformly dull grey on broad frons, face and occiput, everywhere rather densely long black bristled. Ocellar and frontal bristles equally unusually long and strong, clearly longer than upper postocular bristles. Antenna (Fig. 3a) black, 2nd segment with 2 or 3 strong black outer bristles at least as long as basal 2 segments combined; arista long, at least twothirds length of 3rd segment. Palpus black, greyish pollinose, densely long black bristled beneath, 2 or 3 ventral bristles conspicuously long. Labrum long, often nearly as long as head is high.
Thorax black, uniformly bluish-grey dusted and densely black bristled, with distinct almost reddish-brown stripes on lines of bristles: $a c r$ broadly 4-serial but well separated from uniserial $d c$, which are at least 2-serial anteriorly, spreading out to $p h$ bristle, all at least as long as antennal style. Strong marginal bristles in full number including 3 ntpl, 6 (rarely 8) sc bristles, the inner 2 pairs equally long (!), outer pair not much shorter, and all as long as posterior 2 prescutellar pairs of $d c$ and postalar bristles. Pronotum with single long bristle on each side, sides of prosternum with numerous long black bristly hairs, still longer hairs on prothoracic episternum. Spiracles blackish.

Wing clear, somewhat irridescent, with distinct dark veins, brown stigma, and long black costal bristle. Squama pale with black margin, fringes light greyish; halter black, only extreme base of stem brown.

Legs uniformly black, finely greyish pollinose, long and strong. All femora long black pubescent posteriorly and posteroventrally, mid femur with stronger bristly hairs posteriorly and row of long bristles anteriorly. Fore tibia with several long bristly hairs dorsally becoming longer towards tip (Fig. 3b), mid tibia with short pubescence except for 2 or 3 short anteroventral spines on apical third, and hind tibia with 4 to 5 long spine-like bristles dorsally and some shorter similar bristles anteroventrally. Fore basitarsus (Fig. 3b) long ovate, covered with short pubescence only, following tarsomeres clearly longer than deep, though all together at most as long as basitarsus. Posterior 4 tarsi with short pubescence, no longer bristles.

Abdomen dull grey, intersegments (hind tergal margins) narrowly pale; all segments rather densely black pubescent, hind-marginal bristles long. Genitalia as in Fig. 3c-d; lateral lamella covered with long black bristly hairs, apical projection long, finger-like, resembling that of Hilara nigrohirta Collin; tip of hypandrium simple and pointed.

Length. body 3.6-5.0 mm, wing 4.2-5.5 mm.

Female. Resembling male very much, but dark longitudinal stripes on lines of bristles on scutum almost greyish-black, not so reddish-brown as in male. Bristling and pubescence of legs generally same, only fore femur with shorter pubescence posteriorly, but bristling on tibiae practically the same, including that on hind tibia, which is 


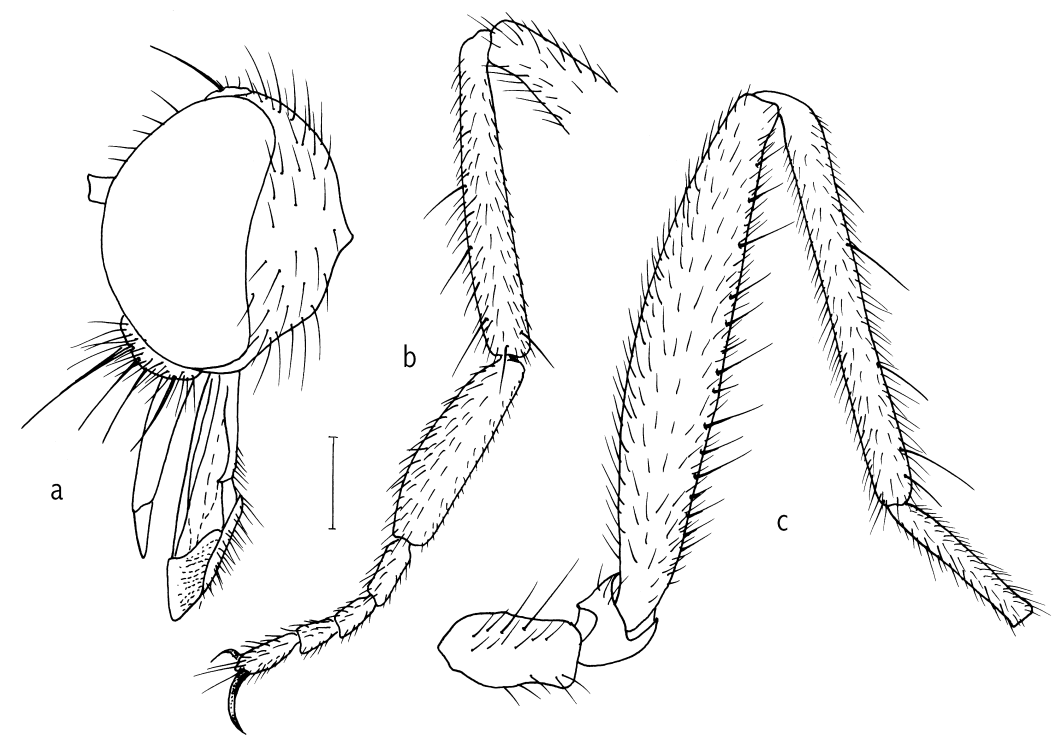

Fig. 4. Hilara coracina Oldenberg, male (Czech Republic, Moravia, Mohelno). - a. Head, lateral view. — b. Fore leg with tip of femur, posterior view. - c. Hind leg, anterior view (apical 4 tarsomeres omitted). Scale $0.2 \mathrm{~mm}$.

unmodified, quite simple and slender. Length: body $3.5-4.3 \mathrm{~mm}$, wing $4.3-4.6 \mathrm{~mm}$.

Differential diagnosis. Hilara caerulescens belongs to the Hilara interstincta group of species and in many respects (including the large size) resembles the very common European $H$. interstincta (Fallén), with which it also occurs together in high mountains. However, the latter has a dull black occiput, mid femora bear a double row of black spines beneath, and scutum is practically unstriped. The female hind tibiae of $H$. interstincta are slightly compressed and bent, whereas in another similar alpine species, H. dimidiata Strobl, the female hind tibiae are curiously dilated apically. Considering the uniformly dull grey occiput, the closest related species is the Mediterranean $H$. dalmatina Strobl, which is generally smaller (body 3.5-4 mm long) with uniformly grey unstriped scutum, longer antennal style, and very conspicuous male genitalia.

Distribution. A species of temperate central parts of Europe, especially in mountains up to $1900 \mathrm{~m}$, as far north as southern warm parts of the Czech Republic and Slovakia, and south to the French and Italian Alps. Obviously not uncommon in the Alps, though I have not yet seen any specimen from Austria; not even Strobl had it in his collection. This is a spring species, mainly present in May and June, on dates ranging from 22 April to 12 July.

Material examined (from north to south). Czech Republic: Moravia mer., Podyjí N. P., Liščí skála, $2.5 \mathrm{~km}$ S of Podmolí, 420 m, 29.IV.16.V. 2001 MT, 1 Ơ leg. Barták \& Kubík (CUP). Slovakia: Slovakia mer., Zadielská dolina 16.V.1964 1 ơ 2 우 (paratypes of Hilara chvalai Straka) leg. M. Chvála (CUP). Switzerland: VS,

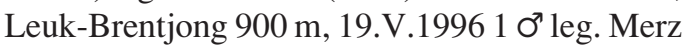
\& Bächli (ETHZ); VS, Leuk-Platten $630 \mathrm{~m}$, 22.IV.1998 9 ơ 9 ㅇ (CBM, ETHZ); Leuk-Pfynwald 23.IV.1998 1 O' leg. Merz \& Botta (CBM); GR, Lenzerheide/Sanas-pans 1700-1900 m, 18.V.1997 1 ○", “over snow" 1 ○’ leg. Merz \& Eggenberger (ETHZ). Italy: Tiroler Dolomiten, Tschamintal 1300-1400 m, 12.-27.VI.1914 9 o", Tiers 16.-22.VI.1914 $30^{\prime 7}$ (lectotype and paralectotypes) leg. L. Oldenberg (ZMB). France: Montgenevre (44.56N/6.43E) (spruce forest) 1800 m, 12.vii.1990 2 ơ leg. M. Barták.

\section{Hilara coracina Oldenberg, 1916 (Figs. 4-5)}

Hilara coracina Oldenberg 1916: 170

Lectotype designation. Described from Bolzano, Italy from "7 $O^{\text {" und } 1}$ ㅇ am 5. und 7. Juni 1914 

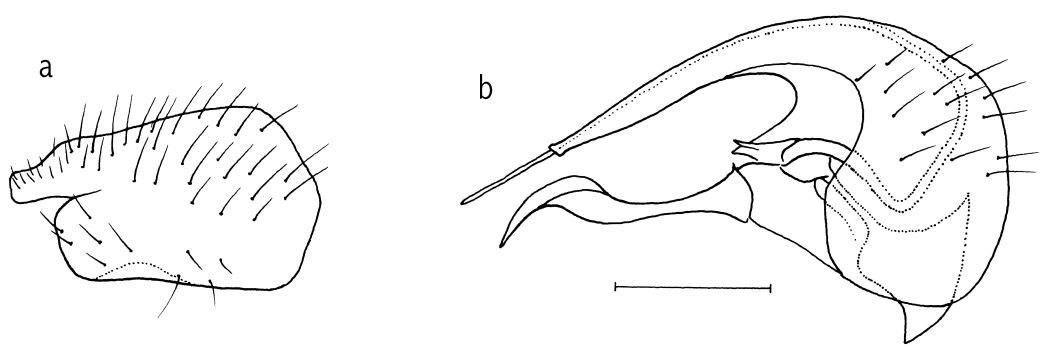

Fig. 5. - Hilara coracina Oldenberg, male (Czech Republic, Moravia, Mohelno). - a. Lateral genital lamella, lateral view. - b. Hypandrium with postgonite in lateral view. Scale $0.2 \mathrm{~mm}$.

bei Bozen am Ostabhang des Eisaktals, an dem vom Virgl nach Campenn führenden Waldwege". There are $60^{\prime}$ and 1 i in DEI, all in very good condition, labelled "Bozen", with dates 5.6.14 $\left(20^{7}\right)$ and 7.6 .14 (4 $0^{7} 1$ o $)$. One male from 7.6.1914 (body length $3.7 \mathrm{~mm}$, wing $4.2 \mathrm{~mm}$ ) is hereby designated as lectotype of Hilara coracina Oldenberg and it was labelled accordingly in 1999; the $5 \sigma^{\circ}$ and $1 \%$ are paralectotypes.

In the DEI Collection at Eberswalde there are in addition to the above syntypic series from Bozen also specimens identified by L.Oldenberg as Hilara coracina from Austria (Gastein), Germany (Arber, ?Wochpass), Italy (Ratzes) and Romania (Mehadia); a further three specimens (1 $0^{7} 2$ \%) from Romania, taken by Oldenberg in May 1904 at Orsova, belong to a new Hilara species that will be described separately.

The five males of Hilara coracina from Finland in the Frey Collection in Helsinki (see below in Material examined) were identified by R. Frey, together with $5 \sigma^{7}$ and 2 of Hilara monedula Collin and $2 \sigma^{7}$ and 2 of $H$. longivittata Zetterstedt, as Hilara quadrifaria Strobl. This identification was accepted by Hackman (1980) in his Finnish List of Diptera and it was mistakenly followed also in the Palaearctic Catalogue (Chvála \& Wagner 1989). Hilara quadrifaria Strobl is an exclusively central European species in distribution, for its full synonymy, redescription and distribution see Chvála (1997a).

Diagnosis. Medium-sized, body about $3.5 \mathrm{~mm}$ long, very deeply black species including legs and halteres, occiput dull black, no frontal bristles. Scutum with a fine bronze-brownish tomentum, and with shining black lines on the small 4-serial $a c r$ and uniserial $d c$. Antennae deep black with style much shorter than 3rd segment, wings clear, legs with spindle-shaped and ventrally black spinose hind femora, male fore basitarsus only very slightly swollen, and female hind tibiae quite slender and simple.

Redescription. Male. Head (Fig. 4a) from all points of view dull velvety black even on occiput, all hairs and bristles black. Frons broad, ocellar bristles slightly longer than upper postocular setae, frontal pair not differentiated. Antenna black, 2nd segment with outer bristles about as long as segment; style short, scarcely two-thirds length of 3rd segment. Palpus black, ventrally with long black hairs and 1 or 2 very long bristles much longer than palpus is long. Labrum shorter than head is high.

Thorax finely brownish to bronze-brown dusted on pleura and mesonotum, viewed from in front scutum dull bronze, with 3 shining black stripes on lines of bristles in anterodorsal view, and uniformly velvety black in posterior view. All hairs and bristles deep black: acr rather small (at most half length of antennal style), almost regularly 4-serial, $d c$ uniserial, becoming longer posteriorly; $h$ bristle very small and fine, $p a$ slightly longer, ih absent, usually 3 strong $n t p l, 1$ $s a$ and $p a$, and 2 pairs of $s c$, outer pair only slightly smaller; long coarse pronotal bristle on each side, prothoracic episternum with long fine hairs, prosternum bare.

Wing practically clear, with contrasting dark veins, an indefinite stigma, and long black costal bristle. Squama very dark grey with black fringes, halter uniformly black.

Legs very black including "knees", everywhere with rather short hairs and no distinct bristles, femora with tendency to be silvery pollinose beneath and armed there with row of small but stouter bristles. All femora with short hairs, even 
mid femur without usual long anterior bristles; hind femur (Fig. 4c) slightly swollen, ventrally with row of not very long but distinct black spinelike bristles; all tibiae slender and with short hairs except preapical bristles, only fore tibia dorsally towards tip with longer bristles (Fig. 4b), and hind tibia (Fig. 4c) with 2 or 3 dorsal bristles at least as long as tibia is deep, anteroventrally short pubescent. Tarsi with all tarsomeres longer than deep, fore basitarsus as in Fig. 4b, long ovate, only slightly stouter than tibia at tip, and covered with short hairs only; in many respects fore legs as in Hilara bohemica Straka.

Abdomen subshining black viewed from above, in lateral view brownish dusted similarly like thoracic pleura; pubescence black, very short, sparse and fine, even hind-marginal bristles fine and inconspicuous. Genitalia as in Fig. 5a-b, finely brownish pollinose in some lights, and everywhere covered with minute black pubescence; lateral lamella with broad blunt terminal projection, tip of hypandrium simple and slender.

Length. Body 2.9-3.7 mm, wing 3.2-4.2 mm.

Female. Resembling male very much in all respects, legs practically without distinct bristles except those dorsally on hind tibiae. Hind femur less stout than in male and ventral spine-like bristles shorter and finer, though distinct as well. Hind tibia quite simple and slender, not curved or compressed. Length: body 3.2-3.9 mm, wing 3.4$4.0 \mathrm{~mm}$.

Differential diagnosis. Hilara coracina should probably belong to the alpine Hilara andermattensis group of species, as defined by Chvála (1999), differing chiefly by the 4-serial acr bristles, the absence of frontal bristles, and the swollen and ventrally spinose hind femora, clearly visible especially in males. The other unique feature is the generally uniform very dull black colouration, especially of legs and halteres, in combination with short antennal style (for a short diagnosis see Chvála [1999]). Also the silvery pollinose venter of femora with a combination of completely black pubescence and bristling, is another unique character within European Hilara species. The other species with femora silvery or white microscopically pilose beneath (as $H$. pruinosa, $H$. albitarsis, $H$. bohemica, $H$. medeteriformis or $H$. calinota) have all at least the base of the abdomen pale pubescent and all belong to different groups or complexes of species. Unfortunately all these species remain often misidentified in collections, as is clearly seen on false identifications given below in the "Material examined".

Distribution. Widely distributed but nowhere common. In northern Europe known from the Baltic coast of Finland, in Sweden north to Ångermanland, found also to the south in Skåne though not yet in Denmark. In central parts of Europe widely distributed from the Czech Republic and Germany (Bayerischer Wald) through Austria and Switzerland and south to the Italian Alps and Romanian Carpathians. Adults are present mainly in June and July, on dates ranging from 19 May to 27 July.

Material examined (from north to south). Finland: AB, Lojo $10^{7} ; A B$, Runsala $20^{7}$; N, Hoplax $10^{\prime \prime}$, all leg. R. Frey (all Hilara quadrifaria Strobl det. R. Frey) (UZMH). AL: Saltvik $20^{\prime \prime}$, Finnström 1 O leg. R. Frey; AB: Lojo $10^{7}$ leg.R.Frey, 27.VI.1963 2 O' 1 이 leg. Krogerus; Runsala 3 O" leg. R.Frey; Vihtijärvi 4.VII.1962 1 ᄋ leg. R. Tuomikoski. N: Esbo, Westend 17.VI.1960 $10^{7}$

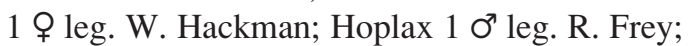
(all UZHM). Sweden: Sk.: Kullaberg 6. and

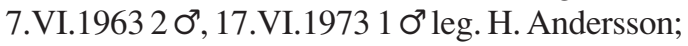
Vaderön 24.VI. and 4.VII.1939 2 ơ, Mölle 30.V.1946 3 ơ 1 o leg. O. Ringdahl. Sm.: Sandreda 4.VII.1927 $10^{7}$ leg. O. Ringdahl; Torsås, Getnabo 7.VI.1992 2 ơ leg. R. Danielsson. Dlsl.: Halleberg VII. $10^{\top}$, leg. T.Tjeder. Dlr.: Floda, Sångån 25.VII.1969 1 이 leg. T. Tjeder. Ång.: Docksta 22.VI.1956 1 ช̛ leg. O. Ringdahl, (all ZIL). Czech Republic: Bohemia bor., BílinaVršíček (mixed wood) 400 m, 28.V.-25.VI.1998 MT 1 O leg. M. Barták; Moravia bor. or., TřinecTyra (compositae flowers) $500 \mathrm{~m}, 19 . \mathrm{V} .199010^{\circ}$ leg. M. Barták (H.bohemica Straka det. Straka 1993); Moravia mer. occ., Pojihlaví, Mohelno (6863) (reserve, hadcová step) 30.V.1995 3 ơ leg. B. Mocek (CUP). Slovakia: Slovakia centr., Kremnické pohorie Mts, Turček env. (on window) 850 m, 22.VI.1979 1 o leg. J. Roháček (H. perversa Old. det. Straka 1983); Pol'ana B. R., Hrončecký grúň res., 12.VI.1999 1 \& leg. J. Roháček (CUP). Germany: Arber (Böhmerwald,

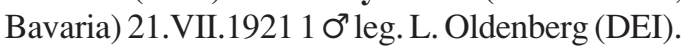
Bayerischer Wald, Spiegelau 4 km N, 890m, 8.VI.1995 1 ㅇ leg. M. Barták (CUP). ?? Wochpass

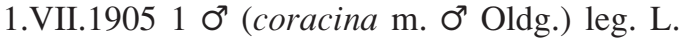




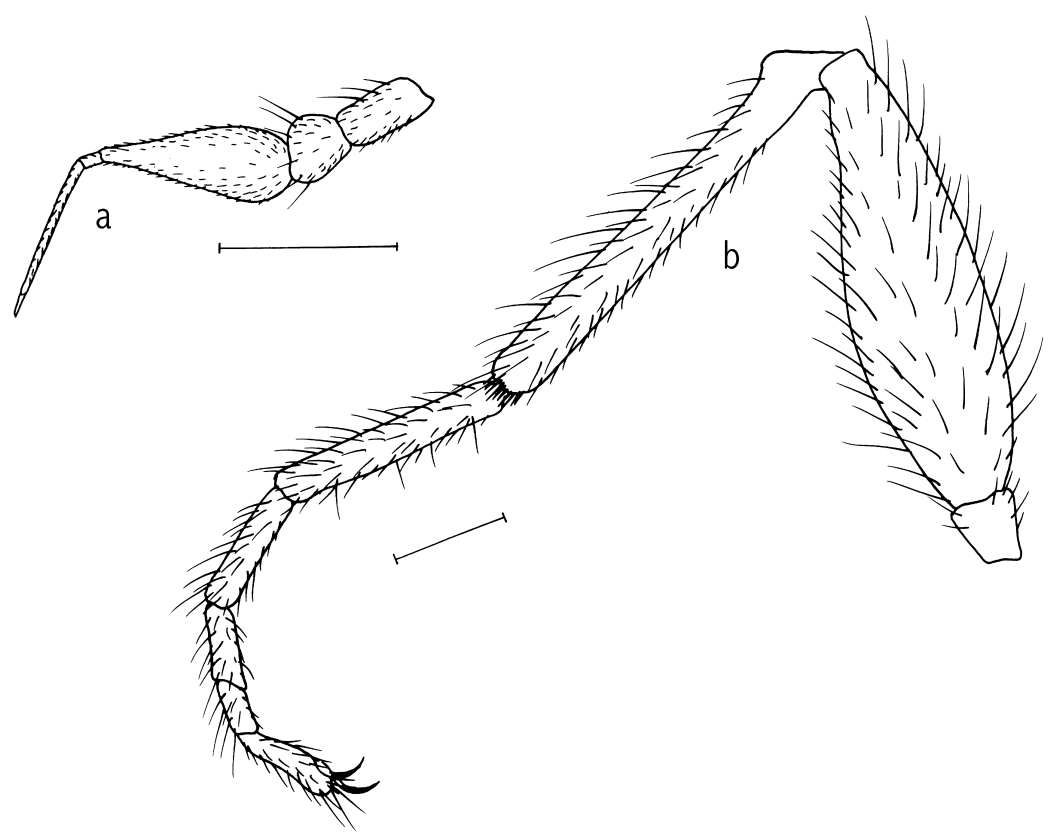

Fig. 6. Hilara perversa Oldenberg, paralectotype male (Schmeks; Czech Republic, Vysoké Tatry Mts). - a. Antenna, inner view. - b. Fore leg, anterior view. Scales $0.2 \mathrm{~mm}$.

Oldenberg (DEI). Austria: Gastein 23.VII.1907 1 ㅇ (“Type") leg. L. Oldenberg (DEI); Styria, Admont-Saugraben 830 m 19.VI.2000 1 ơ leg. M. Chvála (CUP). Switzerland: SH, 520-720 m, Merishausen/Gräte 1.VI.1996 1 \& leg. Merz \& Eggenberger(CBM). Italy: Bozen, 5.-7.VI.1914 $60^{7}$ 1 O (lectotype and paralectotypes) leg. L. Oldenberg; Ratzes (Tiroler Dolomiten) 27.VII.1911 1 o leg. L. Oldenberg (DEI); Romania: Mehadia 12. and 16.VI.1912 $20^{7}$ leg.? L. Oldenberg (DEI).

\section{Hilara perversa Oldenberg, 1916 (Fig. 6)}

\section{Hilara perversa Oldenberg, 1916: 166}

Lectotype designation. The species was described from the Slovak Vysoké Tatry Mts (Giant Tatra) from " $30^{\prime}$ und 7 Q bei Tatrafüred und im benachbarten Kohlbachtal 25-31 Juli 01". Tatrafüred, or Schmeks, is a town Starý Smokovec in central part of the Vysoké Tatry Mts, Kohlbachtal is a near valley Studenovodská dolina. All syntypes are preserved in the DEI Collection at Eberswalde: 10 " labelled "Kohlbach 31.7.01" (without head), the further 20 " are labelled "Schmeks", from 25. and 30.7.01; other 5 \% are labelled "Schmeks
25.7.01", one was captured on "30.7.01" and the last syntypic female is labelled "Kohlbach 31.7.01", all are in very good condition. The male labelled "Schmeks 30.7.01" (body length $2.8 \mathrm{~mm}$, wing $3.6 \mathrm{~mm}$ ) is hereby designated as lectotype of Hilara perversa Oldenberg and it was labelled so by the author in 1999 .

Diagnosis. Uniformly subshining black, tiny slender species (body length about 2.5-3 mm), with all bristles black, long and thin, and few in number; acr 2-serial, $d c$ 1-serial. Fore femora curiously thickened in both sexes; wings brownish, long and narrow, axillary lobe slightly developed.

Redescription. Male. Head velvety black on frons and occiput, lower part of frons and face more brownish-grey; face slightly narrower than frons, as wide as 2nd antennal segment is deep. Pair of ocellar and frontal bristles almost as long, very thin, as long as 3rd antennal segment without style, and as long as slightly forwardly curved postocular bristles. Antenna (Fig. 6a) long and slender, basal segment twice as long as deep, style as long as 3rd segment. Palpus small, blackish, ventrally short black pubescent, armed with single very long black bristle at about middle be- 
neath nearly as long as shining black labrum (of about half length of head height).

Thorax not clearly shining black, everywhere finely greyish pollinose, but the general appearance is almost polished. Large bristles black, long and thin: $1 h, 1$ ih nearly in row of 6-7 equally long 1-serial $d c$ (about as long as antennal style), $2 n t p l$, and 2 pairs of $s c$, hind $n t p l$ and inner pair of $s c$ longest; acr narrowly 2-serial and distinctly diverging, more numerous and smaller (of half length) than $d c$; pronotum with long thin bristle on each side (as long as $d c$ ) and whole prosternum including episternum covered with fine, minute black pubescence. Spiracles blackish.

Wing uniformly light brown, unusually long and narrow, axillary lobe only slightly developed, and long thin black costal bristle. Squama dark grey, fringes brownish. Halter black, unusually long and equally widening towards tip, extreme base of stem paler.

Legs uniformly black, only "knees" very narrowly paler. Except for very thickened fore femur all other parts of legs (Fig. 6b) long and slender, finely densely blackish pubescent, the hairs on tibiae and posterior 4 femora about as long as legs are deep; longer bristles present only anterodorsally on mid femur. All tarsomeres (even on fore legs) clearly longer than deep, at least twice as long; fore basitarsus (Fig. 6b) slender, half as long as fore tibia.

Abdomen subshining black, covered with scattered fine dark hairs. Genitalia not very large, though slightly higher than 6th abdominal segment (the last unmodified segment) and especially characteristic by enlarged semicircular hypandrium, resembling that of $H$. platyura Loew or $H$. lasiochira Strobl. Lateral lamella rather densely, finely dark pubescent, upper terminal projection broadened, apically curved. Figured by Straka (1975: 105) and also by Niesiolowski \& Krysiak (1996:185), although in both cases slightly differently, but the figured male fore leg proves the species was in both cases correctly identified.

Length. body $2.2-2.8 \mathrm{~mm}$, wing $3.3-4.0 \mathrm{~mm}$.

Female. Resembling male in all details including the structure of fore legs. Abdomen pointed, 7 th and following segments including slender cerci greyish dusted. Length: body 2.5-3.0 mm, wing 3.0-3.8 mm.

Differential diagnosis. This species is curious by the very thickened fore femora in both sexes, with clearly "bent knees" of the slender tibiae, and by the unmodified slender male fore basitarsus (Fig. 6b). Its classification within recently recognized natural groups or complexes of species remains still unclear. Hilara perversa is the only western Palaearctic representative of the genus with such "raptorial"-like fore legs; only species of the Far East and Japan, of the clearly unrelated Holarctic Hilara femorata Loew group of species, have similarly swollen fore femora. If this striking character is overlooked in $H$. perversa, then the general shining appearance of the entirely black species with long tarsi, small biserial $a c r$ and less numerous bristle-like uniserial $d c$ are good differential characters. The representatives of the large natural Hilara chorica complex of species may easily be differentiated by the very shortened tarsomeres on fore legs in particular.

Distribution. Described from the High Tatra Mts, Slovakia, recently recorded by Niesiolowski \& Krysiak (1996) also from the Polish part of Tatra Mts (Murzasichle 800 m, 27.VIII.1984 3 specimens). Up to now recorded further only from northern Italy and Romania. Ceianu (1992) found it in Romanian Moldavia, Suceava (CimpulungMoldovenesc 31.V.1981 1 O and Valea Putnei 20.VII.1983 $1 \mathrm{O}^{\mathrm{T}}$ ). A typical summer mountain species, all data are from July and August except for one from the end of May in Romania.

Material examined. Slovakia: Vysoké Tatry Mts, Starý Smokovec 25.-30.VII.1901 2 o’ 6 ㅇ (lectotype and paralectotypes); Studenovodská dolina 31.VII.1901 1 Ơ $^{7} 1$ O (paralectotypes), all leg. L. Oldenberg (DEI). Slovakia centr., Kremnické vrchy, Turček 9.VIII.1970 1 O’ 1 O leg. V. Straka (CUP). Romania: Romania bor., Munti Callimani, Lunca Bradului $15 \mathrm{~km} \mathrm{N,} 1000 \mathrm{~m}$, 13.VII.1988 1 O’ leg. B. Mocek (CUP).

Acknowledgements. The author wishes to thank especially Dr Frank Menzel (Eberswalde) and Dr Marion Kotrba (Berlin, now München) for the loan of all Oldenberg's types under their care. For the privilege to study the most important institutional Diptera Collections, the author is indebted to the following persons (in alphabetical order): R. Danielsson (Lund), J. Götze (Admont), U. Kallweit (Dresden), R. Maier (Copenhagen), B. Merz (Genève), A. C. Pont (Oxford) and P. Vilkamaa (Helsinki). For loans or donation of documentary specimens the author is also very indebted to M. Barták (Praha), B. Mocek (Hradec Králové), J. Roháček (Opava) and R. Rozkošný (Brno). For critical re- 
view of the manuscript and many valuable suggestions the author wishes to thank one anonymous referee, and Maurice Jensen for linguistic corrections. The study was financially supported by the grant 21-3130046 VZ of the Ministry of Education and by the grant No. 206/00/0621 of the Czech Grant Agency.

\section{References}

Ceianu, I. 1992: Contribution to the knowledge of superfamily Empidoidea (Diptera) in Romania. I. - Trav. Mus. Hist. Nat. "Grigore Antipa” 32: 17-48.

Chvála, M. 1971: Redescriptions of Hilara species described by G.Strobl from Spain (Diptera, Empididae). - Acta Ent. Bohemoslov. 68: 322-340.

Chvála, M. 1997a: Eleven new synonymies in European species of Hilara (Diptera: Empididae). - Acta Univ. Carol.-Biol. 41: 293-322.

Chvála, M. 1997b: Empididae. — In: Chvála, M. (ed.), Check List of Diptera (Insecta) of the Czech and Slovak Republics. Karolinum, Charles University Press, Prague. 130 pp.

Chvála, M. 1999: Classification and phylogeny of the Alpine Hilara andermattensis-group (Diptera: Empididae). - Acta Univ. Carol.-Biol. 43: 27-50.

Chvála, M., Barták, M., Beuk, P. \& Merz, B. 1998: 45.
Empididae. - In: Merz, B., Bächli, G., Haenni, J.-P. \& Gonseth, Y. (eds.), Diptera - Checklist, Fauna helvetica 1, Schweizerische Entomologische Gesellschaft. 369 pp.

Chvála, M. \& Wagner, R. 1989: Family Empididae. — In: Soós, Á. \& Papp, L. (eds.), Catalogue of Palaearctic Diptera, Akadémiai Kiadó, Budapest, vol.6. 435 pp.

Collin, J.E. 1961: Empididae. British Flies, University Press Cambridge, vol.6, viii + 782 pp.

Hackman, W. 1980: A check list of the Finnish Diptera. I. Nematocera and Brachycera (s.str.). — Not. Entomol. 60: $17-48$.

Niesiolowski, S. \& Krysiak, I. 1996: Genus Hilara Meigen, 1822 (Empididae, Diptera) in Poland. — Acta Univ. Lodz., Folia Limnol. 6: 77-251.

Oldenberg, L. 1916: Einige neue und alte Hilara-Arten (Dipt.). — Arch. Naturgesch. 81A(9) (1915): 166-172.

Straka, V. 1975: A study of the genus Hilara Meig. (Diptera, Empididae) in Czechoslovakia. — Biol. Práce 21(5): 1-155, Veda, Bratislava. [In Slovak].

Straka, V. 1976: Description of new European species of the genus Hilara Meigen (Diptera, Empididae). Annot. Zool. Bot. Bratislava 116: 1-36.

Strobl, G. 1909: Empididae. — In: Czerny, L. \& Strobl, G. (eds.), Spanische Dipteren. III. Beitrag. Verh. Zool.Bot. Ges. Wien 59: 121-301.

Strobl, G. 1910: Die Dipteren von Steiermark. II. Nachtrag. — Mitt. Naturw. Ver. Steierm. 46(1909): 45-292. 